\title{
The molecular phylogeny of the Sparidae (Pisces, Perciformes) based on two satellite DNA families
}

\author{
ROBERTO DE LA HERRÁN, CARMELO RUIZ REJÓN, MANUEL RUIZ REJÓN \\ MANUEL A. GARRIDO-RAMOS* \\ Departamento de Genética, Facultad de Ciencias, Universidad de Granada, 18071 Granada, Spain
}

\begin{abstract}
In this study, the phylogenetic relationships and which the taxonomic status of the species belonging to the Sparidae family (Pisces: Perciformes) are analysed and revised. This study includes species of this family that are distributed by the North-eastern Atlantic and Mediterranean coasts, is based on the analysis of two satellite DNA families. While one satellite DNA, the centromeric EcoRI family, extends to all the species analysed, the other, the subtelomeric DraI family, is restricted to only six of the 16 species studied. Based on phylogenetic use of these two markers, we conclude that the Sparidae family is composed by two major lineages: one comprising the species of the genera Sparus, Diplodus, Lithognathus, Boops, Sarpa and Spondyliosoma, and one species of Pagellus (P. bogaraveo); and the other lineage is comprised of the species of Pagrus and Dentex, and one species of Pagellus (P. erythrinus). This classification is consistent across the two markers used and clearly contradicts previous morphological phylogenies based mainly on dentition. In addition, the current status and the phylogenetic position of some of the species analysed (i.e. species of Pagrus, Dentex and Pagellus) are not supported by our analyses. Finally, we discuss the value of the morphological characters used until now for the classification of this group of fish.
\end{abstract}

Keywords: phylogeny, recurrent evolution, satellite DNA, Sparidae, taxonomy.

\section{Introduction}

The family Sparidae of the fish order Perciformes comprises approximately 29 genera and 100 species, from which 24 species (10 genera) are described from the north-eastern Atlantic and Mediterranean coasts (Bauchot \& Hureau, 1986). The group includes a large number of species of high economic value. The classification and the phylogenetic relationships of these species, however, remains controversial. Traditionally based mainly on the dentition and diet, the Sparidae family has been divided into three subfamilies: Denticinae, Sparinae and Boopsinae (Tortonese, 1975; see Table 1). Adaptive traits related to feeding, however, have been found in several situations to be highly plastic (in fish, Meyer, 1993; Stiassny, 1996), as is also found with regard to other morphological characters (Chow \& Kishino, 1995; Birstein \& DeSalle, 1998). At the genus level, the genus Sparus, comprising the majority of the current species of the family, was founded by Linneus in 1758. Since then, many authors have proposed different genera for the family Sparidae and the taxonomy of the

*Correspondence: E-mail: mgarrido@ugr.es group has frequently been revised. There has been considerable controversy concerning the validity of the genus Pagrus as a taxonomic unit independent of the genus Sparus (Bianchi, 1984), while the taxonomic status of different species has been successively changed (Bauchot \& Hureau, 1986). Conversely, some conflicts have arisen with respect to the relationships between genera within the group, and, as revealed recently, some inconsistencies appear between morphological and molecular data (Reina et al., 1994; Garrido-Ramos et al., 1995a, 1999; Hanel \& Sturmbauer, 2000).

Satellite DNAs are rapidly evolving sequences. The resolving power of these sequences in systematic studies ranges from the identification of conspecific populations (Elder \& Turner, 1994) to interfamilial relationships of cetaceans (Arnason et al., 1992; Gretarsdottir \& Arnason, 1992). These sequences are considered to be a new promising and useful tool for identifying phylogenetic relationships (Stepien \& Kocher, 1997) and they have been used in recent years for systematic studies (Franck et al., 1994; Garrido-Ramos et al., 1995a, 1999; Mestrovic et al., 2000). We have previously characterized a satellite DNA family, the centromeric EcoRI family (Garrido-Ramos et al., 1994, 1995b), and have 
Table 1 List of the 24 sparid species of the north eastern Atlantic and Mediterranean coasts according to the classification given by Tortonese (1975). The table also includes the 16 species examined and the sequences analysed in this paper

\begin{tabular}{|c|c|c|c|c|}
\hline $\begin{array}{l}\text { Subfamily } \\
\text { (dentition) }\end{array}$ & Genera & Species & $\begin{array}{l}\text { Species analysed } \\
\text { for EcoRI* }\end{array}$ & $\begin{array}{c}\text { Species analysed } \\
\text { having DraI sequences }\end{array}$ \\
\hline $\begin{array}{l}\text { Sparinae } \\
\text { (molariform) }\end{array}$ & $\begin{array}{l}\text { Sparus } \\
\text { Lithognathus } \\
\text { Pagrus }\end{array}$ & $\begin{array}{l}\text { annularis } \\
\text { sargus } \\
\text { bellottii } \\
\text { puntazzo } \\
\text { vulgaris } \\
\text { cervinus } \\
\text { aurata } \\
\text { mormyrus } \\
\text { pagrus } \\
\text { auriga } \\
\text { caeruleostictus } \\
\text { erythrinus } \\
\text { bogaraveo } \\
\text { acarne } \\
\text { bellotii }\end{array}$ & $\begin{array}{c}\text { Z48694 to Z48699 } \\
\text { Z48711 to Z48713, } \\
\text { Z48719 to Z48720 } \\
\text { Z48677 to Z48681, Z48718 } \\
\text { Z48700 to Z48704 } \\
\text { Not analysed } \\
\text { Not analysed } \\
\text { Z21781 to Z21786 } \\
\text { Z48689 to Z48693 } \\
\text { AJ000523 to AJ000525 } \\
\text { AJ000526 to AJ000529 } \\
\text { Not analysed } \\
\text { Z48705 to Z48710, } \\
\text { AJ000530 to AJ000532 } \\
\text { AJ270575 to AJ270580 } \\
\text { Not analysed } \\
\text { Not analysed }\end{array}$ & $\begin{array}{c}\text { No } \\
\text { No } \\
\text { No } \\
\text { No } \\
\text { Not analysed } \\
\text { Not analysed } \\
\text { No } \\
\text { No } \\
\text { AJ009803, AJ009810 to AJ009813 } \\
\text { AJ009802, AJ009804 to AJ009806 } \\
\text { Not analysed } \\
\text { AJ009807 to AJ009809 } \\
\text { No } \\
\text { Not analysed } \\
\text { Not analysed }\end{array}$ \\
\hline $\begin{array}{l}\text { Boopsinae } \\
\text { (incisiform) }\end{array}$ & $\begin{array}{l}\text { Boops } \\
\text { Sarpa } \\
\text { Spondyliosoma } \\
\text { Oblada }\end{array}$ & $\begin{array}{l}\text { boops } \\
\text { salpa } \\
\text { cantharus } \\
\text { melanura }\end{array}$ & $\begin{array}{c}\mathrm{AJ} 270581 \text { to } \mathrm{AJ} 270585 \\
\mathrm{AJ} 270586 \text { to } \mathrm{AJ} 270592 \\
\mathrm{Z} 48682 \text { to } \mathrm{Z} 48688 \\
\text { Not analysed }\end{array}$ & $\begin{array}{c}\text { No } \\
\text { No } \\
\text { No } \\
\text { Not analysed }\end{array}$ \\
\hline $\begin{array}{l}\text { Denticinae } \\
\text { (caniniform) }\end{array}$ & Dentex & $\begin{array}{l}\text { dentex } \\
\text { gibbosus } \\
\text { canariensis } \\
\text { macrophthalmus } \\
\text { maroccanus }\end{array}$ & $\begin{array}{c}\text { AJ270599 \# } \\
\text { AJ570600 \# } \\
\text { AJ270593 to AJ270598 } \\
\text { Not analysed } \\
\text { Not analysed }\end{array}$ & $\begin{array}{c}\text { AJ270601 to AJ270604 } \\
\text { AJ270605 to AJ270608 } \\
\text { AJ270609 to AJ270610 } \\
\text { Not analysed } \\
\text { Not analysed }\end{array}$ \\
\hline
\end{tabular}

*Numbers indicate the EMBL accession numbers for each of the sequences analysed from each species, \# accession number only for the EcoRI consensus sequence.

used it as a phylogenetic marker, analysing the relationships between nine species of the subfamily Sparinae and one of the subfamily Boopsinae (Garrido-Ramos et al., 1999). In this study, we seek to provide a complete vision of the taxonomic and phylogenetic relationships of the family Sparidae. In our analysis, we include six new species representatives of the subfamilies Boopsinae and Denticinae, scarcely analysed previously, and use the information provided by the centromeric EcoRI satellite DNA and by a new satellite DNA family, the subtelomeric DraI family (Garrido-Ramos et al., 1998).

\section{Materials and methods}

Specimens were obtained from both the experimental hatchery of C.I.C.E.M. 'El Toruño' (Consejería de Agricultura y Pesca, Junta de Andalucía; Spain) and from fishing in the Cádiz Bay (SE Spain). We analysed a total of 16 species (Table 1 ).

\section{Cloning and sequencing the subtelomeric satellite DNA}

By means of Southern-blot hybridization and PCR amplification we have demonstrated the presence of this satellite DNA family in only three out of 10 sparid species: Pagrus pagrus, Pagrus auriga and Pagellus erythrinus (Garrido-Ramos et al., 1995a, 1998). As this satellite DNA family can be used as a cladistic diagnostic, we have tried to identify which of the six new species analysed here (Dentex canariensis, D. gibbosus, D. dentex, Boops boops, Sarpa salpa and Pagellus bogaraveo) have this satellite DNA family, by means of PCR, using the primers designed by Garrido-Ramos et al. (1998). Recombinant plasmids containing the amplified DraI sequences of each species (Dentex canariensis, D. gibbosus and $D$. dentex) were used as templates for sequencing by the dideoxynucleotide chain terminator method of Sanger et al. (1977). Sequencing products were analysed by an automated laser fluorescent DNA 
sequencer (Amersham Pharmacia Biotech Europe $\mathrm{GmbH}$, Barcelona, Spain). The list of species having the DraI sequences and the EMBL accession numbers for the sequences obtained are included in Table 1.

\section{Cloning and sequencing the centromeric satellite DNA}

In addition to the 56 EcoRI sequences from 10 sparid species listed in Garrido-Ramos et al. (1999), we have isolated by means of direct cloning or by PCR amplification and subsequent cloning (see primers and conditions in Garrido-Ramos et al., 1999) 32 repetitive units more belonging to six different species: six from Pagellus bogaraveo, seven from Sarpa salpa, five from Boops boops, four from Dentex dentex, six from $D$. canariensis and four from $D$. gibbossus. The sequencing procedure was as described above. The EMBL accession numbers for the sequences obtained are included in Table 1.

\section{Phylogenetic analysis}

We used the two satellite DNA families of the sparid species for phylogenetic inference of the group. As the DraI family is restricted to some species only of the Sparidae, we used this family as a diagnostic marker for the differentiation of species according to its presence or absence. Second, as the EcoRI satellite DNA family is conserved in the whole group, we have used the sequence divergence data between species as the basis of a phylogenetic analysis. We comparatively analysed 88 different EcoRI monomeric units. Multiple alignment was first performed by the program CLUSTAL W 1.7 (Thompson et al., 1997). Comparative intraspecific analysis of EcoRI and DraI monomeric sequences (nucleotide diversity) followed Nei (1987). For phylogenetic analyses, the neighbour-joining method (Saitou \& Nei, 1987) was used because of the short length of the sequence analysed and because of the high genetic distances found between species belonging to different clades, together with the unequal rates of sequence change among lineages (Kumar et al., 1993). Neighbour-joining phylogenetic analyses were carried out using the EcoRI sequences using the MEGA package (Kumar et al., 1993). Genetic distances were calculated according to Tajima \& Nei (1984).

\section{Results}

\section{Analysis of the Dral satellite DNA family}

The DraI satellite DNA family is subtelomerically located on the chromosomes of the three sparid species analysed to date (Pagellus erythrinus, Pagrus pagrus and
P. auriga) (Garrido-Ramos et al., 1998). We demonstrated by means of Southern hybridization and by PCR amplification in a previous study that this satellite DNA was absent from the genome of seven species of the genera Sparus, Diplodus, Lithognathus and Spondyliosoma. Following these procedures, we show here that among the six new species that we analyse, the DraI sequences are present in the genome of the three species of Dentex $(D$. dentex, D. gibbosus and D. canariensis), but absent from the genome of the other three species: Pagellus bogaraveo, Sarpa salpa and Boops boops (see Table 1). The DraI sequences of the Dentex species (10 monomeric units in total) were aligned intraspecifically and the consensus sequences (173 bp in length) obtained from each comparison were compared to those obtained for Pagrus species (nine sequences) and Pagellus erythrinus (three sequences). Intraspecific variability ( 0.048 for $D$. dentex, 0.046 for D. gibbosus, 0.069 for D. canariensis, 0.030 for Pagrus auriga, 0.010 for Pagrus pagrus and 0.075 for Pagellus erythrinus) was consistently less than interspecific divergence. This was 5\% sequence divergence for comparisons between Pagrus species, 11-15\% between Dentex species, $10-14 \%$ between species of Dentex and species of Pagrus, and 10-14\% divergence between any species of Pagrus or Dentex with Pagellus erythrinus.

\section{Analysis of the EcoRI satellite DNA family and the phylogeny of the Sparidae}

The EcoRI satellite DNA is the basic component of the centromeres of the chromosomes of the sparid species. As in the approach followed for the identification of the DraI sequences, we demonstrated by means of PCR or Southern blot the presence of EcoRI sequences in the genomes of the six new species included here. Thus, either by direct cloning, or by PCR amplification and subsequent cloning, we have obtained 32 monomeric units from six new species (six from Pagellus bogaraveo, seven from Sarpa salpa, five from Boops boops, four from Dentex dentex, six from D. canariensis and four from D. gibbossus). According to previous data, those monomeric EcoRI sequences have a length of $187 \mathrm{bp}$ and showed characteristics similar to those found in previously analysed species: (i) the complete sequence is not uniformly useful for the phylogenetic analyses made here, a part of the sequence must be deleted for such purposes (from positions 163-187); (ii) the sequences compared are AT rich (62-67\%); (iii) there is no strong transition/transversion bias; (iv) genetic distances between repeat units of the same species were smaller than genetic distances between repeat units in different species; consistently, phylogenetic inference methods grouped the repeats together by taxonomic affinities; as concerted evolution is revealed for these sequences, we 
used consensus sequences for inferring the phylogeny of the sparids; (v) this satellite DNA family is restricted to the species of the Sparidae family, therefore, an outgroup species is missing for this analysis.

With this taken into account, the multiple alignment of EcoRI consensus sequences of the total of 16 sparid species was used as a source for the phylogenetic analysis. The Jukes-Cantor estimate of the number of nucleotide changes per site $(d)$ between most of comparisons was $0.2<d<1$. As the frequencies of the four nucleotides deviate substantially from equality, but there was no strong transition/transversion bias, we used the Tajima-Nei distance (Tajima \& Nei, 1984). The species analysed were grouped in two major lineages (Fig. 1). The species of Diplodus, Sparus, Lithognathus, Spondilyosoma, Boops, Sarpa and Pagellus (P. bogaraveo) comprising one of the lineages, had an average TajimaNei distance of 0.32 . We can, however, distinguish between two clades within this lineage: the clade Diplodus-Sparus-Lithognathus-Spondilyosoma (average distance of 0.21) and the clade Boops-Sarpa (distance of 0.24), while the situation of Pagellus bogaraveo is uncertain as it is equally distant to each of the two clades (average distance of 0.39 in both comparisons). The species of Dentex, Pagrus and Pagellus (P. erythrinus) comprised the other lineage and had an average Tajima-Nei distance of 0.21 . The mean distance between taxa of the two lineages was 0.88 .

The unrooted tree obtained by neighbour-joining shows two clearly differentiated lineages (Fig. 1). As the EcoRI satellite DNA family is exclusive to the sparid species, there is no root for the tree. Considering the long distances separating the two clades, we can assume a midpoint root in the neighbour-joining tree. Thus, phylogenetic reconstruction from EcoRI consensus sequences of each species demonstrated the existence of two monophyletic groups within the Sparidae family: one composed of the species of the genera Pagrus and
Dentex, including one species of the two analysed here belonging to the genus Pagellus (P. erythrinus), and the other clade composed of the species of the genera Sparus, Diplodus, Lithognathus, Spondyliosoma, Boops and Sarpa, and the other species of the genus Pagellus analysed here ( $P$. bogaraveo). Both monophyletic groups were supported by 100 of 100 bootstrapped trees (5000 replicates).

\section{Discussion}

The current classifications of the Sparidae family are based on morphological traits, mainly in dentition, but it has been demonstrated in other groups of fish such as cichlids that similar evolutionary adaptations can sometimes evolve independently (Meyer, 1993). Adaptive traits related to feeding, for example, can converge in different lineages (Meyer, 1993; Stiassny, 1996). Tooth shape can even change over the life span of individuals in some of these species (Meyer, 1993). Traditionally, the Sparidae family has been divided into three subfamilies: Denticinae, Sparinae and Boopsinae (Table 1). Our data do not, however, support the subdivision of the Sparidae into three subfamilies. Our phylogenetic analyses suggest that the sparids can be assigned to two major lineages: lineage 1, composed of the species of the genera Sparus, Diplodus, Lithognathus, Spondyliosoma, Boops and Sarpa and Pagellus bogaraveo (some species of Sparinae and all analysed species of Boopsinae), and lineage 2 composed of the species of the genera Pagrus and Dentex, plus Pagellus erythrinus (some species of Sparinae and the species of Denticinae).

Both molecular markers used in this study are congruent with this point of view. First, the exclusive presence of DraI satellite DNA family in the genomes of the species of Pagrus, Dentex and in Pagellus erythrinus permits the grouping of these species in a monophyletic lineage apart from the lineage that includes the rest of

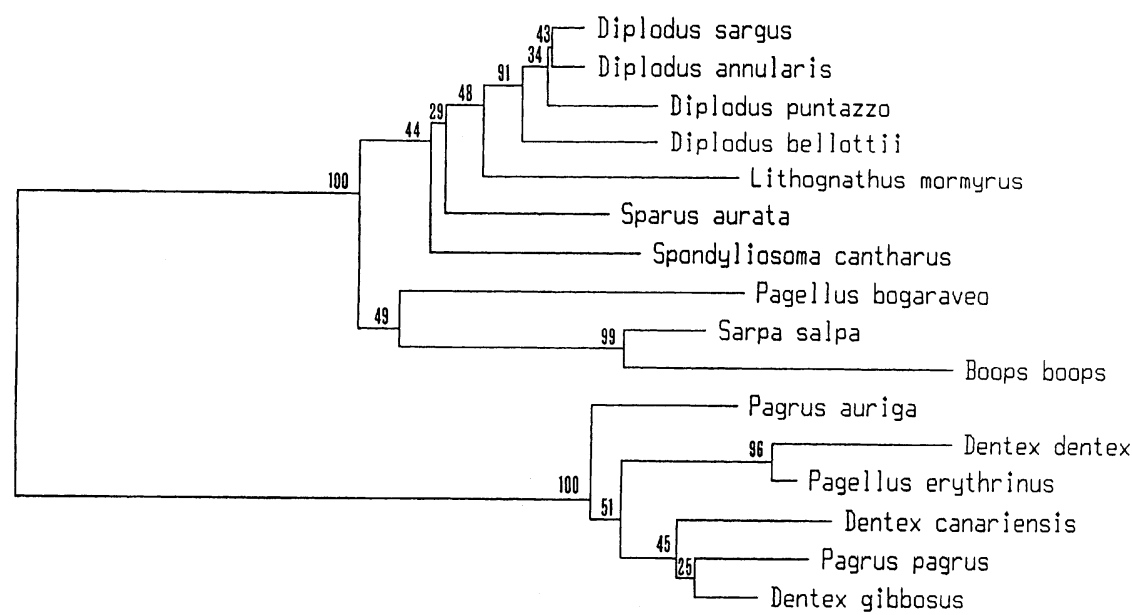

Fig. 1 Unrooted neighbour-joining tree of EcoRI consensus sequences from sparid species. Numbers are bootstrapping indices for the level of support for individual nodes.

(C) The Genetics Society of Great Britain, Heredity, 87, 691-697. 
species. From a phylogenetic standpoint, the sharing of the same satellite-DNA family can be used for associating related species. If two species share one satelliteDNA family, they must have diverged more recently than other species not having that satellite-DNA family. This allows the use of repetitive sequence families as cladistic markers (Arnason \& Widegren, 1986; Murata et al., 1993; Van Den Busche et al., 1993; Hartley \& Davidson, 1994a,b).

Secondly, the analysis of the sequence divergence for EcoRI satellite DNA sequences supports the results with DraI sequences (Fig. 1). The two lineages share the centromeric EcoRI satellite DNA family, as demonstrated here and elsewhere, supporting the monophyly of the entire group of sparids. These data indicate that the EcoRI satellite DNA must have appeared early in the common ancestor of the sparid species, while DraI must have appeared after the spread of the Pagrus-DentexPagellus erythrinus lineage. We cannot, however, disregard the theoretical possibility that DraI may have been lost in a common ancestor of the other lineage.

Within the first lineage, the genus Sparus was considered early on to be composed of Sparus aurata and the current species of Pagrus, until the revision of Cuvier (1817). The dentition differences in this case are scant and many authors claimed a single genus embracing all these species. This study and previous work (Bianchi, 1984; Reina et al., 1994; Garrido-Ramos et al., 1995a, 1999; Hanel \& Sturmbauer, 2000) supports the reinstatement of the genus Pagrus and the existence of a large degree of divergence between the genera Pagrus and Sparus.

The species of Diplodus appear as a monophyletic group. The relationships within this genus inferred from EcoRI satellite DNA are consistent with the morphological relationships described by De la Paz (1975). The inclusion of D. puntazzo as a taxon within this genus and not as an independent genus (Puntazzo puntazzo or Charax puntazzo) is supported by this study. The more closely related species within this genus are $D$. sargus and D. annularis, as proposed by De la Paz (1975). Finally, we found enough sequence divergence between $D$. annularis and D. bellottii at the cytogenetic level (Amores et al., 1993) to differentiate these two species, that at the morphological level are particularly similar (Cárdenas, 1978).

It is apparent that Spondyliosoma, Sarpa and Boops are related by morphology (subfamily Boopsinae) and by the molecular data (Fig. 1). As considered traditionally, Boops boops and Sarpa salpa are closely related species (the common synonym of Sarpa salpa was Boops salpa, Bauchot \& Hureau, 1986). The genetic distance between the species $(0.24)$ is similar to other intergeneric comparisons (i.e. Diplodus-Sparus and Diplodus-Litho- gnathus) and much higher than conspecific distances (average distance of 0.10 for Diplodus species). Recent phylogenetic analyses based on mitochondrial DNA (Hanel \& Sturmbauer, 2000) support the existence of a third lineage within the Sparidae composed of these three species (Spondyliosoma cantharus, Sarpa salpa and Boops boops), but not the fourth species (Oblada melanura) of the former subfamily Boopsinae. This last species is related to the rest of Sparinae species (Hanel \& Sturmbauer, 2000). We do not, however, find support to separate Spondyliosoma cantharus, Sarpa salpa and Boops boops from the species of Sparinae.

Special consideration should be given to the genus Pagellus, which contains four species: the red seabream $(P$. bogaraveo $)$, the axillary seabream $(P$. acarne $)$, the common pandora ( $P$. erythrinus) and the red pandora $(P$. bellottii). We analysed two species of this genus: $P$. bogaraveo and $P$. erythrinus. These two species appeared in our study as highly divergent species, each being included in a different lineage. P. erythrinus is a species closely related to Dentex dentex. Both $P$. erythrinus and $D$. dentex share the DraI satellite DNA in their genomes, together with the remaining species of Dentex and those of Pagrus, satellite DNA that is absent from the genome of $P$. bogaraveo. Moreover, the sequence divergence for EcoRI sequences is substantial between the two species of Pagellus and associates $P$. bogaraveo with species of Boops and Sarpa. It therefore appears that the genus Pagellus is an artificial genus. The paraphyly of the genus Pagellus was also found by Hanel \& Sturmbauer (2000). As in our study they found that $P$. bogaraveo and $P$. acarne were closely related to the Diplodus species, while P. erythrinus and P. bellottii, were related to the species of Dentex and Pagrus.

The second lineage includes all species of the genera Dentex and Pagrus as well as Pagellus erythrinus. The generic assignments within this clade indicate, again, the paraphyly of the three genera (Hanel \& Sturmbauer, 2000). Dentex canariensis and D. gibbosus (both previously ascribed to a different genus, Cheimerus), form a distinct clade together with one species of Pagrus (P. pagrus) (mean distance of 0.14 for EcoRI sequences). Dentex dentex and Pagellus erythrinus appear as sister taxa (distance of 0.14), in a different clade to that of $D$. canariensis and D. gibbosus (distance between these two clades: 0.25). Pagrus auriga appears, finally, as a taxon independent of these two clada (distances of 0.18 and 0.28 , with respect to the first and the second clade, respectively).

In conclusion, we have found several inconsistencies in the current phylogeny and taxonomic assignments based on morphological traits, with respect to the results obtained from two molecular markers for the Sparidae family. It has already been proven that some 
morphological characters in fish are clearly adaptive, as in the dentition of sparid species (Cataudella et al., 1980). It has been also demonstrated, however, that characters such as those of trophic types or body shape may be affected by recurrent evolution in different lineages (Meyer, 1993; Stiassny, 1996). Several reports based on molecular studies have indicated that, in fish, morphological phylogenies are some times incongruent (Chow \& Kishino, 1995; Kocher et al., 1995; Birstein \& DeSalle, 1998). Molecular data presented in this study again show a considerable deviation from the phylogeny inferred from morphology, indicating the need to reevaluate the morphological characteristics of fish as systematic indicators.

\section{Acknowledgements}

This work was supported by a grant of the Spanish CICYT (PB96-1402), and by a grant of Plan Andaluz de Investigación (Group No. CVI0200).

\section{References}

Amores, A., Martínez, G., ReinA, J. AND Alvarez, M. C. 1993. Karyotype, C-banding, and Ag-NOR analysis in Diplodus bellottii (Sparidae, Perciformes). Intra-individual polymorphism involving heterochromatic regions. Genome, $\mathbf{3 6}$, 672-675.

ARNASON, U., GRETTARSDOTTIR, S. AND WIDEGREN, B. 1992. Mysticete (baleen whale) relationships based upon the sequence of the common cetacean DNA satellite. Mol. Biol. Evol., 9, 1018-1028.

ARnASON, U. AND WIDEgren, B. 1986. Pinniped phylogeny enlightened by molecular hybridizations using highly repetitive DNA. Mol. Biol. Evol., 3, 356-365.

BAUChOt, M. L. AND hUREAU, J. C. 1986. Sparidae. In: Whitehead, P. J. P., Bauchot, M. L., Hureau, J. C., Nielsen, J. and Tortonese, E. (eds) Fishes of the NorthEastern Atlantic and the Mediterranean, Vol. 2. UNESCO, Paris.

BIANCHI, G. 1984. Study on the morphology of five Mediterranean and Atlantic sparid fishes with a reinstatement of the genus Pagrus Cuvier 1817. Cybium, 8, 31-56.

BIRSTEIN, V. J. AND DESAlle, R. 1998. Molecular phylogeny of Acipenserinae. Mol. Phyl. Evol., 9, 141-155.

CÁRDENAS, S. 1978. Sur la présence de Diplodus bellottii (Steindachner, 1882) sur les côtes européennes. Bull. Off. Natn. Péch. Tunisie, 2, 97-99.

CATAudella, S., PERIN Riz, P. AND SOlA, L. 1980. A chromosome study of eight Mediterranean species of Sparidae (Pisces, Perciformes). Genetica, 54, 155-159.

CHOW, S. AND KISHINO, H. 1995. Phylogenetic relationships between tuna species of the genus Thunnus (Scombridae, Teleostei): inconsistent implications from morphology, nuclear and mitochondrial genomes. J. Mol. Evol., 41, 741-748.
CUVIER, G. 1817. Le régne animal distribué d'aprés son organisation, pour servir de base á l'histoire naturelle des animaux et d'introduction á l'anatomie comparée. Nouvelle Édition, Paris, 1, 272.

DE LA PAZ, R. 1975. Systématique et phylogense des sparidae du genre Diplodus Raf., (Pisces, Teleostei). Travaux et Documents de L'O.R.S.T.O.M, no. 45. O.R.S.T.O.M., Paris.

ELDER, M. AND TURNER, J. 1994. Concerted evolution at the population level; pupfish HindIII satellite DNA-sequence. Proc. Natl. Acad. Sci. U.S.A., 91, 994-998.

FRANCK, J. P. C., KORNFIELD, I. AND WRIGHT, J. M. 1994. The utility of SATA satellite DNA sequences for inferring phylogenetic relationships among the three major genera of Tilapiine cichlid fishes. Mol. Phyl. Evol., 3, 10-16.

GARRIDO-RAMOS, M. A., DE LA HERRÁN, R., JAMILENA, M., LOZANO, R., RUIZ REJÓN, C. AND RUIZ REJóN, M. 1999. Evolution of centromeric satellite DNA and its use in phylogenetic studies of the Sparidae family (Pisces, Perciformes). Mol. Phyl. Evol., 12, 200-204.

GARRIDO-RAMOS, M. A., DE LA HERRÁN, R., RUIZ REJÓN, C. AND RUIZ REJÓN, M. 1998. A satellite DNA of the Sparidae family (Pisces, Perciformes) associated with telomeric sequences. Cytogenet. Cell Genet., 83, 3-9.

GARRIDO-RAMOS, M. A., JAMILENA, M., LOZANO, R., CÁRDENAS, S., RUIZ REJón, C. AND RUIZ REJóN, M. 1995a. Phylogenetic relationships of the Sparidae family (Pisces, Perciformes) inferred from satellite DNA. Hereditas, 122, 1-6.

GARRIDO-RAMOS, M. A., JAMILENA, M., LOZANO, R., RUIZ REJÓN, C. AND RUIZ REJón, M. 1994. Cloning and characterization of a fish centromeric DNA. Cytogenet. Cell Genet., 65, 233-237.

GARRIDO-RAMOS, M. A., JAMILENA, M., LOZANO, R., RUIZ REJÓN, C. AND RUIZ REJÓN, M. 1995b. The EcoRI centromeric satellite DNA of the Sparidae family (Pisces, Perciformes) contains a sequence motive common to other vertebrate centromeric satellite-DNA. Cytogenet. Cell Genet., 71, 345-351.

GRETARSDOTTIR, G. AND ARNASON, U. 1992. Evolution of the common cetacean highly repetitive DNA component and the systematic position of Orcaella brevirostris. J. Mol. Evol., 34, 201-208.

HANEL, R. AND STURMBAUER, C. 2000. Multiple recurrent evolution of trophic types in northeastern Atlantic and Mediterranean seabreams (Sparidae, Percoidei). J. Mol. Evol., 50, 276-283.

HARTLEY, S. E. AND DAVIDSON, W. S. 1994a. Distribution of satellite DNA sequences isolated from Arctic char; Salvelinus alpinus, in the genus Salvelinus. Can. J. Fish Aquat. Sci., 51, 277-283.

HARTLEY, S. E. AND DAVIDSON, w. S. 1994b. Characterization and distribution of genomic repeat sequences from Arctic char (Salvelinus alpinus). In: Beamont, A. R. (ed.) Genetics and Evolution of Aquatic Organisms, pp. 271-279. Chapman \& Hall, London.

KOCHER, T. D., CONTROY, J. A., MCKAYE, K. R. AND STAUFFER, J. R. 1995. Similar morphologies of cichlid fish in Lake Tanganyika and Malawi are due to convergence. Mol. Phyl. Evol., 2, 158-165. 
KUMAR, S., TAMURA, K. AND NEI, M. 1993. MEGA: Molecular Evolutionary Genetics Analysis, Version 1.01. The Pennsylvania State University, University Park, PA.

MESTROVIC, M., MravinAC, B., JUAN, C., UGARKovic, D. AND PLOHL, M. 2000. Comparative study of satellite sequences and phylogeny of five species from the genus Polarus (Insecta, Coleoptera). Genome, 43, 776-785.

MEYER, A. 1993. Phylogenetic relationships and evolutionary processes in east African cichlid fishes. Trends Ecol. Evol., 8, 279-284.

MURATA, S., TAKASAKI, N., SAITOH, M. AND OKADA, N. 1993. Determination of the phylogenetic relationships among Pacific salmonids by using short interspersed elements (SINEs) as temporal landmarks of evolution. Proc. Natl. Acad. Sci. U.S.A., 90, 6995-6999.

NEI, M. 1987. Molecular Evolutionary Genetics. Columbia University Press, New York.

ReINA, J., MARtíNeZ, G., AMORES, A. AND ALVAREZ, M. C. 1994. Interspecific genetic differentiation in western mediterranean sparid species. Aquaculture, 125, 47-57.

SAITOU, N. AND NEI, M. 1987. The neighbor-joining method: a new method for reconstructing phylogenetic trees. Mol. Biol. Evol., 4, 406-425.
SANGER, F., NICKLEN, S. AND COUlSON, A. R. 1977. DNA sequencing with chain terminating inhibitors. Proc. Natl. Acad. Sci. U.S.A., 74, 5463-5467.

STEPIEN, C. A. AND KOCHER, T. D. 1997. Molecules and morphology in studies of fish evolution. In: Kocher, T. D. and Stepien, S. D. (eds) Molecular Systematics of Fishes, pp. 1-11. Academic Press, San Diego.

STIASSNY, M. L. J. 1996. An overview of freshwater biodiversity: with some lessons from African fishes. Fisheries, 21, 7-13.

TAJIMA, F. AND NEI, M. 1984. Estimation of evolutionary distance between nucleotide sequences. Mol. Biol. Evol., 1, 269-285.

THOMPSON, J. D., HIGGINS, D. G. AND GIBSON, T. J. 1997. CLUSTAL $W$, Version 1.7. EMBL, Heidelberg.

TORTONESE, E. 1975. Fauna de Italia 'Osteichthyes'. 'Pesci Ossei.', Vol. XI. pp. 82-122. Calderini, Bologna.

VAN DEN BUSCHE, R. A., BAKER, R. J., WICHMAN, H. A. AND HAMILTON, M. J. 1993. Molecular phylogenetics of Stenodermatini bat genera: congruence of data from nuclear and mitochondrial DNA. Mol. Biol. Evol., 10, 944-959. 